\title{
Some Thoughts on Slang
}

\section{Jonathon Green London and Paris}

\begin{abstract}
Slang is a self-sufficient, subversive, oppositional subset of the English language. It has given a tongue, by no means inarticulate, to the marginal, the criminal and the dispossessed for at least half a millennium. But it is hard to pin down: even the etymology of the word 'slang' remains unsubstantiated. Perhaps inevitably it challenges concrete linguistic definition, remaining a source of argument: is it a full scale language or simply a lexis of synonymy. And what exactly constitutes a 'slang' word, what qualifies it for inclusion in that lexis? Whatever the 'truth' it remains a flourishing and endlessly self-inventive channel of communication. As a slang lexicographer of thirty years' experience, I have come to ask another question: to what extent does any of this matter? Slang is important, slang dictionaries are important, even slang lexicographers are important. But this need to pin down, to categorise, to set in place: is it vital? Does it not run almost perversely in the face of slang's own imperatives: to represent without compromise - through its obsessions and its relentlessly negative, cynical take on the world - a side of humanity that some, including myself, see as our most human.
\end{abstract}

On croit que l'on maîtrise les mots, mais ce sont les mots qui nous maitrisent.

Alain Rey

Arseholes, bastards, fucking cunts and pricks. Ian Dury, 'Plaistow Patricia' (1977) 


\section{Introduction}

Slang is the language that says no. Born in the street it resists the niceties of the respectable. It is impertinent, mocking, unconvinced by rules, regulations and ideologies. It is a subset of language that since its earliest appearance has been linked to the lower depths, the criminal, the marginal, the unwanted or even persecuted members of society. It has been censored, ignored, shoved to one side and into the gutter from where it is widely believed to take its inspiration and in which it and its users supposedly find a home. It remains something apart, and for many that is where it should stay.

Yet if such negatives are true, then they are imposed from the outside. From the prejudiced, the ignorant, the fearful, the censorious. The reality of the language is that it is vibrant, creative, witty, and open to seemingly infinite re-invention. It is voyeuristic, amoral, libertarian and libertine. It is vicious. It is cruel. It is self-indulgent. It is funny. It is fun. Its dictionaries offer an oral history of marginality and rebellion, of dispossession and frustration. They list the words that have evolved to illumine and to challenge those states. It is supremely human. Given its position on the margins one might see it as a means of self-affirmation: I denigrate / blaspheme / am obscene therefore I am. Shouting dark words into the darkness.

It subscribes to nothing but itself - no belief systems, no true believers, no faith, no religion, no politics, no party. It is the linguistic version of Freud's id, defined by him (Freud 1964: 73) as 'the dark, inaccessible part of our personality. [...] It is filled with energy reaching it from the instincts, but it has no organisation, produces no collective will, but only a striving to bring about the satisfaction of the instinctual needs subject to the observance of the pleasure principle.' And in English slang it, translating id from the Latin and the original German, can mean sex or either of the bodily parts it requires for consummation. So be it.

Excluded from the standard world the slang user rejects standard language and substitutes a code within which he/she feels secure and which serves to define him/herself. Of course no-one exists purely in slang-world. It is feasible, perhaps, in a closed society such as a prison, but rarely elsewhere. One must discard slang to enter 'real life' just as one discards casual clothes to go to work. Otherwise it plays a vital role. It offers articulacy to the otherwise inarticulate, or at least those who lack the mastery of standard usage. And like beauty, articulacy is wholly relative.

There are few languages that have resisted a slang. Perhaps they are spoken in the few countries that have no city, slang's necessary crucible. The languages, of course, are different: some vastly, some relatively slightly, but all are different. But in slangs as in the people who speak them: plus ça change. The details differ, the big picture is much the same. Slang has a story, and that story has universal themes.

So what do these themes tell us? That the basics remain consistent in slang as in much that is human: sex, money, intoxication, fear (of others), aggrandizement (of oneself). As one might expect, the focus is on those areas of existence that slang itself would define as 'the down and the dirty'. This is the most broad-brush of assessments, 
but looking at the lexis that I have entered into my own database, I find this thematic hierarchy:

THEMES

Crime and Criminals

Drink, Drinks, Drinking and Drunkards

Drugs

Money

Women (of various descriptions, almost none

of them complementary)

Fools and Foolish

Men (of various descriptions, not invariably, but

often self-aggrandising)

Sexual Intercourse

Penis

Homosexuals/Homosexuality

Prostitute and Prostitution

Vagina

Policeman and Policing

Masturbate and Masturbation

Die, Death, Dead

Beat or Hit

Mad

Anus or Buttocks

Terms of Racial or National abuse

(+ derivations c. 1000, with blacks and Jews

Leading the parade)

Defecate and Defecation \& Urinate and Urination

Kill or Murder

Unattractive

Angry

Fat

Vomit and Vomiting

Oaths
NO. OF HEADWORDS

5012

4589

3976

3342

2480

2403

2183

1740

1351

1238

1185

1180

1034

945

831

728

776

634

570

This is an anglophone lexis, but I would not expect that any slang would vary to a great extent. One might even position slang as the true esperanto - the real international language. Not of course an actual esperanto - since it is found in so many different languages - but a figurative one, in the over-arching imagery that runs through all slang's varieties and in its role in communication and as a statement of self.

It might be said that the very narrowness of its thematic 'waterfront' is the best testament to its utility. Stripped down, modernist, cutting edge - at whatever time, that 
is, that it has reflected the currently 'modern' and whatever edge has been at that moment 'cutting'.

Which to me proves that even if the individual terms that make up the vocabulary may be dismissed - and it is a far from accurate dismissal - as 'ephemeral', the persistence of these themes ensures that slang lasts. The imagery does not vanish; it is not short-term. It reflect the way that we think of certain topics. One might call it stereotyping since it is often in stereotypes that slang deals but could a better synonym be psychological 'shorthand'?

\section{The etymology of the word slang}

Where - as a word - does slang come from? Before looking, however constrainedly, at what comprises this particular lexical subset, what about the word itself? Does it remain what my great predecessor Eric Partridge (1933, q. in Green 2008: xii) called it: 'that prize-problem word'?

Although the currently accepted first use of the word in the context of a 'counterlanguage' is dated to 1756 , there is evidence through the 1740s of alternative senses, though all are underpinned by some idea of duplicity: 'a line of (possible criminal) work' (1741), 'nonsense' (1747) and as a verb 'to cheat, to swindle, to defraud' (1741) and 'to abuse or banter with' (1749). There is also the tempting evidence of 'A Plan for a Hospital for Decayed Thief-Takers', a document attributed to the thief-taker and receiver Jonathan Wild, which contains the line: 'The master who teaches them should be a man well versed in the cant language, commonly called the Slang Patter, in which they should by all means excel.' Wild was hanged in 1725; the pamphlet is dated 1758 . And while it was allegedly 'printed from a manuscript, said to be written by Jonathan Wild while under condemnation in Newgate' its signature 'Henry Humbug' almost certainly suggests a later, satirical author. ${ }^{1}$

The word was yet to reach the dictionary and no attempt at an etymology was proposed prior to that of the mid-19th century slang lexicographer John Camden Hotten (1859: lv-lvi):

The word SLANG is only mentioned by two lexicographers,-Webster and Ogilvie. Johnson, Walker, and the older compilers of dictionaries give slang as the preterite of sling, but not a word about SLANG in the sense of low, vulgar, or unrecognized language. The origin of the word has often been asked for in literary journals and books, but only one man, until recently, ever hazarded an etymology, - Jonathan Bee, the vulgar chronicler of the prize-ring. With a recklessness peculiar to ignorance, Bee stated that SLANG was derived from "the slangs or fetters worn by prisoners, having acquired that name from the manner in which they were worn, as they required a sling of string to keep them off the ground". ${ }^{2}$ 
Hotten's own belief was that 'Slang is not an English word ; it is the Gipsy term for their secret language, and its synonym is Gibberish another word which was believed to have had no distinct origin' (Hotten 1873: 41).

Neither Barrère and Leland (1889-90) nor Farmer and Henley (1890-1904) took things any further in their slang dictionaries. It was left to the professionals at the ongoing $O E D$. Sir William Craigie, dealing with slang in its first edition took that Dictionary's usual cautious view on such matters: it was 'a word of cant origin, the ultimate source of which is not apparent'; this refusal to hazard any further guess has not been modified since (although the on-line $O E D$ is under revision it has yet to reach slang). Craigie compounded his rejection of possible origins with a further note: 'the date and early associations of the word make it unlikely that there is any connection with certain Norwegian forms in sleng- which exhibit some approximation in sense.' This flat declaration ran quite contrary to the views of another Oxford philologist, Walter Skeat, whose Etymological Dictionary of the English Language had originally appeared between 1879-8. Skeat attributed slang unequivocally to the Scandinavian languages. Listing such terms as the Norwegian sleng 'a slinging, an invention, device, stratagem; also a little addition or burthen of a song, in verse and melody'; ettersleng '(lit. after-slang), a burthen at the end of a verse of a ballad'; slengjenamn 'a nickname'; slengjeord 'an insulting word or allusion'; the Icelandic slyngr and slunginn 'versed in a thing, cunning'; and the Swedish slanger 'to gossip', Skeat showed himself free of all doubt: 'that all the above Norweg[ian] and Icel[andic] words are derivatives from sling is quite clear [...]. I see no objection to this explanation' (Skeat 1909) Other etymologists tended to follow Skeat. Henry Bradley who succeeded Sir James Murray as editor of the $O E D$ in 1915, accepted the Norwegian connection. So too did Professors Ernest Weekley and H.C. Wyld in subsequent studies. More recently Eric Partridge, never one to let caution fetter his own deductive skills, modified the Norwegian thesis in his own etymological dictionary Origins (Partridge 1966). For him slang is a dialect past participle of the verb sling, which has its roots in Old and Middle English and links to Old Norse, thus giving the concept of 'slung' or 'thrown' language. This conveniently encompasses the abusive side of slang, e.g. 'sling off at' and is duly bolstered by the Norwegian slenga keften (also cited by Skeat) lit. to 'sling the jaw', and thus, literally, to use slang, as well as Skeat's slengjeord. The current, on-line OED remains unconvinced.

\section{The definitions of slang}

Thus the roots, or lack of them; what of the definition? Set firmly amid respectable language by the $O E D$, slang as a word remains essentially unchanged as to its definitions and in its use, even if it continues to develop as a vocabulary. The philologists and lexicographers remain generally consistent in their opinions. Since the $O E D$ laid down lexicographical law they may have replaced simple definition by more complex explanation, but they differ only in the nuances. 
'Slang is a poor man's poetry' suggested John Moore in You English Words (Moore 1961: 42), a sentiment underpinning the title of Michael Adams' study Slang: The People's Poetry (Adams 2009). And like the poor, to whom must be attributed credit for the coinage, or at least the popularisation of a major portion of its vocabulary, slang is always with us. Whether, as one observer suggests, it is the working man of language, doing the lexicon's 'dirty work' or, as Moore and Adams imply, it represents the lyrical creativity of the disenfranchised or, as its many critics still proclaim, it has nothing but the most deleterious effects on 'proper speech', slang remains a law unto itself. Nor is it easy to define.

As a linguistic phenomenon it surely predates Christ. John Camden Hotten, as keen as any other Victorian scholar to find antecedents in the classical and pre-classical worlds, offers the readers of his Slang Dictionary (Hotten 1859: xlix-1) an alluring, if somewhat fantastical picture of this 'universal and ancient' species of language:

If we are to believe implicitly the saying of the wise man, that "there is nothing new under the sun," the "fast" men of buried Nineveh, with their knotty and door-matty looking beards, may have cracked slang jokes on the steps of Sennacherib's palace ; and the stones of Ancient Egypt, and the bricks of venerable and used up Babylon, may, for aught we know, be covered with slang hieroglyphics unknown to modern antiquarians[.]

And the Phoenicians, the Greeks and the Romans all, we may presume (and in the case of the latter pair, we know), had their own slangy speech. As a word in itself however, it only emerges into the (printed) language in the mid-18th century. The Oxford English Dictionary (1933), which included only that slang terminology which occurred in literature and in the 16th and 17th century glossarists, defined the term as 'The special vocabulary used by any set of persons of a low or disreputable character; language of a low a vulgar type,' and adds, 'Language of a highly colloquial type, considered as below the level of standard educated speech, and consisting either of new words or of current words employed in some special sense'. In a strictly linguistic sense the word is so far first recorded in 1756, when in act I of William Toldervy's play The History of the Two Orphans one finds 'Thomas Throw had been upon the town, knew the slang well; $[. .$.$] and understood every word in the scoundrel's dictionary.' And immediately$ one is faced by a possible question. Was Throw's 'slang' a reference to his speech, or to a duplicitous and probably criminal way of conducting himself? Given the final phrase, one may suppose that the reference is indeed to his vocabulary. In which case the slang in question is no more than a synonym for cant, or criminal jargon, and does not involve the more general sense of today. ${ }^{3}$ By the turn of the century the definitions had broadened.

As well as standing synonymous with cant, slang began to be used as an alternative to jargon or professional/occupational slang by such luminaries as Charles Kingsley (in a letter of 1857). George Eliot (in Middlemarch) referred not merely to the slang of shopkeepers (decrying 'superior' as used of comestibles) but added that 'all choice of words is a slang [...] correct English is the slang of prigs who write history and essays. And the strongest slang of all is the slang of poets' (Eliot 1872: Bk I, Ch. XI). Dickens, 
in an essay in his journal Household Words in September 1856, attacks slang, but seems to be targeting the affectations and idiosyncrasies of various styles of standard speech, rather than the lists of vulgar synonyms (for drunk, etc.) which he appears despite himself to revel in itemising. More notably the word, if not the vocabulary, had been enlisted in Standard English by the mid-century and dignified by John Keble (in 1818), Thackeray (in Vanity Fair 1848) and many other respectable users. In 1858 Trollope, in Dr. Thorne, speaks of 'fast, slang men, who were fast and slang and nothing else', a citation that points up both their language and their rakehell, buckish style. Across the Channel Balzac, in Splendeurs et Misères des Courtisanes, proclaimed of argot that 'there is no more energetic or colourful language than that of this subterranean world' (Balzac 1970 [1847]: 441) even if Hugo's 'condemned man' shrank from it as 'an odious phraseology grafted on the general language, like a hideous excrescence' (Hugo 1928 [1829]: 399). But Hugo still gave it a whole chapter in Les Miserables. Zola, typically in L'Assommoir (1877), made it a cornerstone of literary realism.

Francis Grose in his dictionary of 1785 defines it as 'cant language'. But Grose does not offer slang as a headword and the first dictionary definition is to be found written by Noah Webster in 1828: 'low, vulgar, unmeaning language'. Webster's successors offered a variety of takes. Examples include the 1864 Webster-Mahn, which amended its definition to read: 'low, vulgar, unauthorized language; a colloquial mode of expression, especially such as is in vogue with some class in society.' Bolles (1863) referred to 'low and abusive language'; discussing 'The Rationale of Slang,' the Overland Monthly defined it as the 'spontaneous outburst of the thought-power become vocal' and noted that the lexis had no purpose 'other than emphasis, or illustration' (Caldwell 1870: 187 and 188). In his Dictionary of the English Language (1860) Webster's rival, Joseph Worcester called it 'vile, low, or vulgar language; the cant of sharpers or of the vulgar; gibberish.' Brander Matthews, writing in Parts of Speech (1901) on 'The Function of Slang' defined it as 'a word or a phrase used with a meaning not recognized in polite letters, either because it had just been invented, or because it had passed out of memory. [...] [A] collection of colloquialisms gathered from all sources, and all bearing alike the bend sinister of illegitimacy' (Matthews 1901: 188).

The Century Dictionary (1889-1891) has 'Slang [...] colloquial words and phrases which have originated in the cant or rude speech of the vagabond or unlettered classes or, belonging in form to standard speech, have acquired or have had given them restricted, capricious, or extravagantly metaphorical meanings, and are regarded as vulgar or inelegant.' The Standard Dictionary (1895) retained value-judgments, but managed a solid assessment: '1. Inelegant and unauthorized popular language, consisting of words and phrases of low or illiterate origin and use, or of legitimate expressions used in grotesque, irregular, or metaphorical senses not approved by reputable usage and good taste[.] 2. The cant or jargon peculiar to thieves and vagrants.'

In 1913, the New Standard Dictionary explained slang as 'the speech or dialect of a special sect, profession, or class of persons' and added that slang is used for 'expressions that are either coarse and rude in themselves or chiefly current among the 
coarser and ruder parts of the community.' In the same year the New International Dictionary opted for 'Originally, cant of thieves, gypsies, beggars, etc.; now, language or words consisting either of new words or phrases, often of the vagrant or illiterate classes, or of ordinary words or phrases in arbitrary senses, and having a conventional but vulgar or inelegant use; also, the jargon of a particular calling or class of society; popular cant.' The $O E D$, in an entry written at the same time, offered the definition noted above. The New Encyclopedia Britannica (1982), in a discursive entry written by the cant collector David Maurer, calls it 'unconventional words or phrases that express either something new or something old in a new way. It is flippant, irreverent, indecorous; it may be indecent or obscene. Its colourful metaphors are generally directed at respectability, and it is this succinct, sometimes witty, frequently impertinent social criticism that gives slang its characteristic flavour. Slang, then, includes not just words but words used in a special way in a certain social context'.

To turn to more recent definitions, John Simpson of the $O E D$ has explained that 'as a rule of thumb we classify a slang word as an alternative to a more formal word, typically used by a subset of the speech population, and a colloquial term as an informal term used widely in the speech community'. ${ }^{4}$ The current on-line Merriam-Webster has 'an informal nonstandard vocabulary composed typically of coinages, arbitrarily changed words, and extravagant, forced, or facetious figures of speech'. Gale Cengage Learning (n.d.) has '[a] type of informal verbal communication that is generally unacceptable for formal writing. Slang words and phrases are often colorful exaggerations used to emphasize the speaker's point; they may also be shortened versions of an often-used word or phrase'. Wikipedia states that slang is 'the use of informal words and expressions that are not considered standard in the speaker's dialect or language. Slang is often to be found in areas of the lexicon that refer to things considered taboo (see euphemism). It is often used to identify with one's peers and, although it may be common among young people, it is used by people of all ages and social groups.' The Urban Dictionary, in sway to lexicographic relativism, offers a choice of 33 variant definitions, of which the most popular is the self-congratulatory 'the only reason Urbandictionary.com exists'. The few more reasoned alternatives seem to be far less favoured by the users.

Slang has also elicited a good many condemnations. Johnson was of course at pains to rid his dictionary of vulgarity, and his initial commission had been to prepare a lexicon of purified English. Slang rarely entered the standard dictionaries, although Elisha Coles allowed some cant in 1676 (justifying his inclusion by explaining that 'Tis no Disparagement to understand the Canting Terms: It may chance to save your Throat from being cut, or (at least) your Pocket from being pick'd' [Coles 1676: 'To the Reader') and Nathan Bailey offered an entire cant appendix in 1730. Critics pontificated de haut en bas on both sides of the Atlantic. Typically John F. Genung who in 1893 announced that 'slang is to a people's language what an epidemic disease is to their bodily constitution; just as catching and just as inevitable in its run. [...] Like a disease, too, it is severest where the sanitary conditions are most neglected' (Genung 1893: 32). The idea of slang as a 'disease'; or a 'perversion', not simply of language but of society 
at large permeates such remarks. Few, however, could equal the editor James C. Fernald who commenced his essay 'The Impoverishment of the Vocabulary: Cant, Slang, Etc.' in Expressive English (1918) thus:

The touch of decay is upon all things earthly. Frost, rain, and wind are casting down the mountains, and the rivers are washing the rock-dust far out into the sea. [...] The Pyramids , stripped of the casing of hewn stone that once covered them are now but rude, though mighty towers in the lonely desert. The Parthenon [...] was desolated long ago[.] The stately monuments of imperial Rome are dismantled from the to-and dust-embedded from the base. Language shares the same tendency to decay. (Fernald 1918: 238)

We may laugh: it would seem that Mr Fernald cried. And continued:

'Slang, for the most part, comes up from the coarse and more ignorant portion of the community. Reading but few books, and those usually of no literary merit, they have nothing to hold them up to high standards of speech. [...] Even words and phrases once excellent in meaning come to express some idea of the saloon or the gutter. If these expressions are vigorous, they quickly become current, for feeble, lethargic, and uninventive minds are glad to be caught up and carried along by those of more originality and force, who are yet not too far above their own grade. Thus some word or phrase [...] will go down street after street, through whole sections of a city. The low theaters catch it up, the saloons pass it over the bar, the yellow journals print it, business men who deal with the rough element adopt it, children learn it from their playmates. (Fernald 1918: 247-248)

[Slang] saves the trouble - and the glory — of thinking. The same cheap word or phrase may be used for any one of a hundred ideas[.] Slang is the advertisement of mental poverty. [...] [I]t so largely comes from the coarse and rude elements of our population, or even from the baser associations and pursuits. (Fernald 1918: 253)

And since ' $[\mathrm{t}]$ he stir of the lower life is constantly bringing to the surface mud, slime, antique carving or inlaid work perverted to some base or ignoble use', those who have the culture and education must 'hold fast to what they know is good and beautiful in accepted standards' (Fernald 1918: 253).

Forty years on, writing a 'Case Against Slang' for the English Journal Milton Millhauser was far less apocalyptic, indeed, somewhat defensive, admitting that

None of this [critique] may be particularly welcome to the student, who [...] seems to regard education as a process that will improve him without changing him in any particular. (For that matter, there is an earthly wisdom in his buoyancy; it will not hurt our case to qualify it a little with good humor and concede that things are not always their logical extremes.) But at least we can make our analysis honest, specific, and direct. "Slang is a kind of speech that belittles what it conveys. It was developed to express a few widely prevalent attitudes and therefore lacks precision and variety. You should avoid it because it is inadequate to critical thinking and because it imposes a cynical or flippant tone on your serious ideas." We can make it as clear and as precise as that. And we can feel that, stating the central rather than peripheral objections, we have moved away from snobbery and 
academic prejudice and related our position to the actual business of communication. (Millhauser 1952)

More recently the French writer Daniel Pennac dismissed it all as no more than a second-rate lexis of the disempowered:

Slang isn't a language, it's merely vocabulary[.] [T] he under-dog's lexicon is so poor that most of these words are quickly carried off by the winds of history: they're twigs, just twigs, too little thought to weigh them down. (Pennac 2010: 175)

He added that 'hardly any of them land in the dictionary' although quite what constitutes 'the dictionary' was left unspecified.

Yay or nay, the reality remains that posited by Bethany K. Dumas and Jonathan Lighter in their 1978 essay 'Is Slang a Word for Linguists?':

Annoyance and frustration await anyone who searches the professional literature for a definition or even a conception of SLANG that can stand up to scrutiny. Instead one finds impressionism, much of it of a dismaying kind. (Dumas and Lighter 1978: 5)

And of all the definitions on offer there is much to be said for Lighter's own synthesis, in the Cambridge History of the English Language:

So taking into account the various definitions in dictionaries as well as the more detailed treatments of such authors as Henry Bradley, Stuart Flexner [...] H. L. Mencken, and Eric Partridge, the following definition will be stipulated [...]: Slang denotes an informal, nonstandard, nontechnical vocabulary composed chiefly of novel-sounding synonyms (and near synonyms) for standard words and phrases; it is often associated with youthful, raffish, or undignified persons and groups; and it conveys often striking connotations of impertinence or irreverence, especially for established attitudes and values within the prevailing culture. (Lighter 2001: 220)

\section{Is there a 'standard' for slang?}

Etymology and definition aside, there is also the question of what, in terms of the words themselves, is slang. And what is not. The dictionary and other definitions did not attempt to answer this, until in 1933, Eric Partridge writing his pioneering overview Slang To-day and Yesterday, offered some 17 criteria by which one might judge a word to be slang. The lexicologist Julie Coleman, in her forthcoming history The Life of Slang (2012), has reduced the qualifications to 11. In 1978 Dumas and Lighter had cut them down to four. In all cases these calculations would appear to be the product of reverse engineering the vocabulary. Yet in answering their own question, Dumas and Lighter have made it clear that slang is not, ultimately, a word for linguists, that it cannot be shoehorned into 21 , let alone four sizes that fit all. 
This is a lexicographer's essay and not a linguist's. Its subject is the words, not pictures of words. Its aim is therefore the accretion of the lexis and the background to that accretion rather than the linguistic status of the register. For all the criteria, for all the inconsistent yet ultimately similar definitions, one is left, like the judge who instinctively recognises pornography but still cannot say exactly what it is, as knowing it when one meets it. Michael Adams, a linguist whose own interest in slang began with his study of the language used in TV show Buffy the Vampire Slayer (Adams 2003) agrees: '[S]lang is what it is. You'll know it when you hear it' (Adams 2009: 49). For him much is down to context and the need to create a social link to those with whom one is speaking. Simply checking a dictionary definition, let alone multiple definitions, offer no help. As fellow slang linguist Connie Eble puts it: 'Slang cannot be defined independent of its functions and use' (Eble 1996: 12). And both cite James B. McMillan:

[T]he basic problem of slang lexicology — definition of the class - has not been solved [...]. Until slang can be objectively identified and segregated (so that dictionaries will not vary in labeling particular lexemes and idioms) or until more precise subcategories replace the catchall label SLANG, little can be done to analyze linguistically this kind of lexis. (McMillan 1978: 146)

It is, of course, quite possible that I reject the linguistic aspects of slang because I lack the intellectual equipment to approach them. But true or otherwise, I still see slang first and foremost less as a language phenomenon but as a psychological one: it seems visceral, hard-wired. A need. But perhaps I flatter it, this mongrel subset of a greater social marginality.

So is there any sort of unifying factor, anything that bonds slang's wide-ranging lexis? So fissiparous are the suggested qualifications that I prefer something more abstract. An élan, as it were. So for me it is this, a link that rather than obeying the rigid strictures of linguistics, is impressionistic, culled from thirty years' immersion in the vocabulary, based on the accumulation of approaching 600,000 citations. At its heart, even its most obscene and gutter-dwelling heart, it is subversive. So many of its terms do no more than turn standard usage upside down. Appropriating them for reinterpretations that mock their lost respectability. If one looks again at my taxonomy, there are many negatives, but where are the terms of congratulation, of kindness, of caring, sharing or compassion. There are none. Or to use slang's own curt dismissal, sweet fuck all.

\section{The creation myth}

It would seem that the idea of slang must come from somewhere. People require that it should come from somewhere. It has creation myths. Like the Biblical original they are almost certainly unsound. 
For English slang, or to be more precise for cant, the language of criminal beggars that represents the first collections of the form, the story is based around one Cock Lorel. His exploits are recounted in Cock Lorel's Bote, published sometime prior to 1513. The name Cock Lorel, used in cant to mean the leader of a gang of rogues, combines the adjective cock, first-rate, and losel, a worthless rogue, a profligate. It is usually found as a proper name and features largely in the literature of Elizabethan villainy. As described in the anonymously written verses, he is a 'ship-master', whose 'crew' is a group of rogues drawn from the workshops and gutters of London. Together they 'sail' the country, engaging in a variety of villainies. He appears in a number of works, as well as in the glossaries compiled by Awdeley (whose Fraternity of Vagabonds, c.1561, was 'confirmed by Cock Lorel') and Rowlands (in Martin Markall, Beadle of Bridewell, 1610), who suggests that while he was 'the most notorious knaue that ever lived' (S.R. 1610: G3 ${ }^{\mathrm{v}}$ ) his 'captain's' role was purely allegorical and that he was, in fact, a tinker. In all mentions he remains at the head of his marauding beggars, sometimes plotting against the state, on one occasion even entertaining the Devil to dinner. According to Rowlands' generally fictitious 'history' of the canting crew, Cock Lorel's rule supposedly lasted c.1511-33. As well as supposedly establishing a number of rules whereby his villains should conduct themselves, he was the first to lay out the 'quartern of knaues called the five and twentie orders of knaues,' a hierarchy of beggary much imitated in a succession of canting books.

But that is all, and while England's early cant collections - Robert Copland's Hye Waye to the Spitel House (c.1535), Thomas Awdelay's Fraternity of Vagabonds (c.1560) and Thomas Harman's Caveat for Common Cursetours (c. 1565) - all listed the 16th century's anglophone begging vocabulary, none made any serious effort to trace its roots. In theory at least, the origins of France's equivalent, argot, are more specific. Ollivier Chereau, sets them out on the opening page of his Jargon ou Langage de l'Argot reformé [...] Tiré et recueilli des plus fameux argotiers de ce temps (1628). It is indeed the first occasion on which the word itself has been found in print:

Antiquity teaches, and the Doctors of Argot inform us, that a King of France, having established the Fairs of Niort, Fontenay[-le-Comte] and other towns in Poitou, many people wished to trade in haberdashery; in order to deal with which [situation] the senior haberdashers assembled and ordered that those who wished to be admitted as haberdashers should be received by their seniors, naming and calling the small merchants péchons [lit. children, i.e., beginners] the others bleches [small merchants], and the richest of them coesmelotiers hurés [head, i.e. chief merchants]. Then they laid down a certain language among them, with some ceremonies to be held for those who professed themselves merchants.

When, Chereau continues, a number of these merchants ran through their funds and needed to expand their trading into other fairs, they encountered a number of pauvres geux (lit. 'poor beggars'), who not only traded but augmented their funds through theft and trickery. The legitimate merchants taught them their 'initiate' language - argot - in 
turn the beggars taught them their larcenous tricks. 'Thence came so many celebrated Argotiers who established the order that followed'.

In both cases the realities were doubtless less specific. And slang, rather than cant, seems to have no established origins, mythical or otherwise. Other than a single, indispensable breeding-ground: the city.

\section{Slang and the city}

'SLANG,' pronounced Hotten in 1859, 'represents that evanescent, vulgar language, ever changing with fashion and taste, [...] spoken by persons in every grade of life, rich and poor, honest and dishonest. [...] Slang is indulged in from a desire to appear familiar with life, gaiety, town-humour, and with the transient nick names and street jokes of the day. [...] Slang is the language of street humour, of fast, high and low life. [...] Slang is as old as speech and the congregating together of people in cities. It is the result of crowding, and excitement, and artificial life.' (Hotten 1859: vii, viii, xlix and 1).

Slang is the lexical roman noir, the unfettered gangsta of language. It is a city pidgin, the tongue of the street. Like the tramp I see almost daily on my walks along a road near my flat in Paris, it lies cheerfully in the gutter. It may be gazing at the stars, but far more likely beneath the skirts of passing women.

Slang is urban. The countryside has region-based dialect, or did, since in the UK at least it has been eroding since the industrial revolution began moving former peasants off the farm and into the factory. Here, it is apparent, they brought some dialect with them, hence the wide range of terms now slang that are underpinned by such original usage. But on the whole one may suggest a simple rule: no city, no slang. It seems always to have been so: among the earliest known slang is that found in such classical authors as Martial and Catullus and both drew on the speech of Rome, a great city, for their sources.

Or if not a city as such, then a gathering where there might be trading and Hotten's 'congregating together of people'. The earliest instances of French argot came from tradesmen and merchants, and even if the vagabonds from whom Harman and others drew their lists of cant are seen as wanderers, their orientation was urban: their relative sophistication made the peasants in isolated villages easy pickings. Their supplies would have been purchased in London or some equivalent conurbation. England's capital city was booming; its population has been estimated at 120,000 at the mid-16th century and by 1600 at a quarter of a million. The expansion was inexorable. By the time Francis Grose published his dictionary in 1785 it was about to top the million mark. Hotten's 1859 dictionary had a potential audience of three million and Farmer and Henley lived in a city of approximately double that. There was plenty of room for slang.

And what is it, this thing that the city and its language have between them? If one looks at definitions other than those in which linguists have struggled to pin this elusive creature to their dissecting tables, the over-riding suggestion is of speed, fluidity, 
movement. The words that recur in dictionary and other definitions are 'casual', 'playful', 'ephemeral', 'racy', 'humorous', 'irreverent'. These are not the terminology of lengthy, measured consideration. The words themselves are twisted, turned, snapped off short, re-launched at a skewed angle. Some with their multiple, and often contrasting definitions seem infinitely malleable, shape-shifting: who knows what hides round their syllabic corners. It is not, I suggest, a language that works out of town; it requires the hustle and bustle, the rush, the lights, the excitement and even the muted (sometimes far from muted) sense of impending threat. To use slang confidently one needs that urban cockiness. It doesn't work behind a pair of oxen, even athwart a tractor. Then there are the value judgements: 'sub-standard', 'low', 'vulgar', 'unauthorized'. The word we are seeking is 'street'. Street as noun, more recently street as adjective. The vulgar tongue. The gutter language.

Slang, it is often suggested, represents the user's innate inarticulacy. Their inability to use standard language. My own researches would deny such assumptions. As James Murray makes clear in the diagram that is included in the first edition of the $O E D$, slang, like technical language or dialect, is simply one more equal variation on the basic 'English language'. It is not hierarchically 'lower' even though 'low' is an adjective regularly ascribed to its terminology and indeed its speakers. Nor does it imply monosyllabic mumblings. The reality is that slang - never more clearly a product of the city that creates it - remains in a state of constant reinvention. And that reinvention is not coming from elite sources. It is harder now to argue that slang is a secret language, as was undoubtedly true of cant. The speed of modern information transfer makes that level of secrecy almost impossible. Nonetheless the need for a level of perceived secrecy remains: when a slang word is coined it may well enjoy a period, however brief, of 'invisibility'. But once it has become 'revealed' then the immediate need is for recoinage. A term may be ephemeral (though much slang is remarkably long-lived), but the imagery behind it, the great recurrent themes of the lexis remain the same. Sexual intercourse will always come down to man hitting woman; the penis will always be some form of knife, gun or club; the vagina remains a source of masculine fear, and is seen as a narrow, twisting, dangerous alley. But there are 1500 synonyms for the first and a thousand apiece for the latter duo.

\section{Some heresies}

I have been collecting and codifying slang for thirty years. The headwords that make up the entirety of my first dictionary, published in 1984, would fit with room to spare within the letter ' $S$ ' as published in my latest of 2010 (Green 2010). I hope I have learnt more than a little, though one learns more with every new headword listed, each new sense added, the constant discovery of citations that reveal an earlier use. Let me, then, offer some heresies: 
The official definitions of slang are ultimately a waste of time, intellectual marginalia for a supremely non- (but not anti-) intellectual code.

And does the etymology of the word slang really matter? Because it remains unknown. Slang is an evocation of (marginal/rebellious/contrary) self. Again, the etymology of the term is unnecessary icing on the cake. Is it, to keep things culinary, over-egging the imagistic custard to suggest that like the great human givens that provide its vocabulary, slang too simply is. Perhaps I do it too much honour. Yet how can I not admire something that has reached so far beneath the moralizing skin.

In 1998 I coined, or perhaps dug up from a subconscious memory, the term counterlanguage to describe slang (the term had existed earlier, but in other contexts). I modelled it quite consciously on the term counter-culture which was frequently used to describe the youth movements of the 1960s. ${ }^{5}$ But since then I have been challenged. Is slang a genuine language? Or is it no more than an aggregation of words. A lexis. If a language demands the fulfilment of certain rules: pronunciation, word order, grammar, then no, it is not. ${ }^{6}$ It is marginal, created and spoken by the marginal, expressing marginality. Those who use it may see it as a language, they may be wrong. One of its own posited etymologies, eliding $s$ for secret and lang for language, suggests that the belief is deep. But that suggested etymology is wrong. Slang may be, or rather may have been secret, but no matter: it still fails the tests that render it a fully fledged language. What it is, perhaps, is a lexis of synonymy. There are themes: topics it embraces, the philosophy of its use ('counter') but even if it demands dictionaries, it is not a language as such.

Yet all that said, the diagram with which Sir James Murray, that dictionary's first editor, prefaces the first edition of the OED (1933) sets slang alongside jargon, technical terms, dialect and other linguistic groups, and all are seen as equally valuable subsets of the central 'English language'.

The current $O E D$ on line states thus in its definitions of language:

1.a. The system of spoken or written communication used by a particular country, people, community, etc., typically consisting of words used within a regular grammatical and syntactic structure.

In which case, no. Victor Hugo, in the Hunchback of Notre-Dame, evoked the 'kingdom of Argot' and all its supposed citizens, but that was fiction. I recommend the description, a glorious piece of fantasy, but I cannot use it as justification here. By this definition slang is not a system. But let us look further:

2.a. The form of words in which something is communicated; manner or style of expression.

Then yes, slang is certainly that. And here the $O E D$ even cross-references to slangism and slanguage. 
A further heresy. The history of slang's use. Good history demands at least a degree of solid material. So does the analyst of slang. But as slang lexicographers we are making a vast and complex concrete structure with no choice but to settle its foundations on sand - well-packed sand at best, shifting sand, even quicksand at worst.

Such records that we have of early slang use are as frustrating as they are insufficiently informative. Slang was not a privileged discourse; slang was thus left largely unrecorded. The earliest material on which we draw is minimal, quite fragmentary. Some 13th century passion plays in France, a few terms in Chaucer or Piers Ploughman, the trial, in 1455, of the Coquillards in Dijon, the near incomprehensible poetry of Villon, Mateo Alemán's Guzmán de Alfarache (15991604), the so-called beggar books of 16th century Europe. This is not a solid record. And in all cases these are pieces of underworld jargons, of criminal codes rather than general slang. Yet the fact that records are relatively scanty in no way 'proves' that even cant emerged fully developed in, to take the UK as an example, Robert Copland's glossary of c.1531 or, in Germany, first in 1479 and then the Liber Vagatorum of 1510. As for slang 'proper', France's bas-langage, literally 'low language' - slang as used by the butcher, the baker and their urban peers - the term does not exist, at least as so far recorded in England, until 1756. I do not care. That there are no records in no way 'proves' the language's non-existence. I cannot 'prove' that I am right, but I believe unreservedly that I am. I believe in a natural, even hard-wired human drift from conformity. In language as in other aspects of existence.

The dictionary, which to the best of its writer's ability must deal with unimpeachable facts, cannot allow itself this luxury - and nor can I in making one. But in theory, if not in practice, I can and do.

The slang dictionary (especially that offering citations) is an oral history of marginality and rebellion, of dispossession and frustration. Little capons on dunghills made of shifting sands. Adding up the words of slang vocabulary, with its infinitely repetitive list of themes, is not wholly necessary. There will continue to be sex and drugs, the whore and the policeman, the thief and the drunk, the unattractive, the mad and all the rest: slang will continue to produce synonyms to describe them. Like the accumulation of money for the very rich, who no longer need it, the amassing of the dictionary is no more than a means of 'keeping score'. Or if one seeks an alternative image, slang lexicography - perhaps all lexicography - is an attempt to map a territory that remains fluid, shifting and in the end unmappable. The lack of full and/or accessible records ensures - even with the near daily advances in what is now to be found via the Internet - that we must leave blank spaces on our maps. 'Here Be Dragons' or anthropophagi - or at least we hope so. But the 'game' will continue whether or not the score is maintained; the territory exists, mapped or otherwise. The interested world requires its guides.

And that dictionary, that short-lived, unfinished scorecard, that map that can never fill in every territory, is inadequate in almost every way. It stands as an authority, it displays itself as concrete, but it is clay from top to toe. It is made, after all, by human beings. It is incomplete - how else can it be when slang is in constant evolution? - it 
takes as its starting point an arbitrary date based on circumstances beyond lexicographical control. Its definitions may be correct but its dating almost invariably is not or at least very well may not be - governed as it has to be by the essential serendipity of research, however devotedly pursued. Its etymologies aim for pertinence, but are too often leaps in the dark, however inspired, and there is, there has to be at times, an admission (perhaps tacit) of guesswork. Its orthography, since of all languages slang remains the most resolutely oral, can be equally debatable. And despite that orality, a guide to its pronunciation is never even attempted. What the lexicographer knows and attempts to pass on to the reader exists only in the shadow of just how much he or she does not know.

None of which, however, in any way invalidates the dictionary's supremely necessary existence. Nor that of the dictionary-maker's job. But one must never forget that the great river the lexicon and its maker attempts to tame would and does flow on quite regardless.

Finally: the dictionary-maker, the lexicographer. The war photographer, crowding forward to capture the agony of the wounded or the sorrow of the refugee and offering help to neither is condemned as a voyeur. So is the slang lexicographer. Or would be were anyone to notice; the registry of human language is somewhat less remarkable than that of human atrocity. Yet the slang collector is perhaps even more the voyeur since he - it is usually he even if slang's leading lexicologist is a woman - need take no risks. Field research is no good for citations. The street is too agitated, too noisy to set down a fair copy of what it creates; the library, along with on-line resources such as Google Book search or Project Gutenberg, provide more certain examples. But watching footage of the London riots of 2011, and reading the rioters' tweets and their vainglorious, self-justifying comments in newspapers and via the Internet I was brought up sharp as never before by the abyss between me and 'them'.

For slang's lexicographer, male, middle-aged, middle-class, it is the great escape. Sex and drugs and rock 'n' roll and never leave your desk. Even more so with the Internet. Anatomists of the underbelly. Dr Frankensteins with our monster dictionaries. Letting them free to wander in the name of our unattained, protected lives. Voyeurs of other people's dramas. Flaneurs, to be kinder, in the streets - some lit brightly, some less so - of slang's languages. The lexis undoubtedly leans to pimping and prostitution, crime and imprisonment, violence and cruelty, drugged and drunken debauches, but the lexicographer is neither whore nor thief, thug nor prisoner, addict nor drunkard. Or not professionally. He is a linguistic reporter: the job is to collect knowledge, to explicate it, and to disseminate the information that emerges. A voyeur, and ideally an informed one. Nor are we merely voyeurs upon the sensational. We are heartless; we have no human interest. Nor human interest stories. Just words, words, words. The beggar is whipped, the whore has a back-story, the junkie dies. We do not care. Only if, frustratingly, impudently, they remain mute.

The lexicography of slang might be represented as a great jigsaw puzzle. Constantly turning the pieces until one fits another and gradually, so very gradually, the picture emerges. The task of the lexicographer is to make those pieces available, even if the 
picture on the box remains fluid, malleable, contradictory. Only the colours - all primaries - are maintained. Like a market trader one lays out one's stock. There is no compulsion on any customer to buy, but what is there is there and the passer-by may look, assess and even purchase. Nothing is 'good' or 'bad', 'better' or 'worse. And nothing is forbidden. For all its sexism, racism, and over-riding cynicism, slang remains an equal opportunities employer.

I have come, over thirty years, to take what I do very seriously. This is not something, as an English person, that I am supposed to admit - the casual amateur remaining the national pose of choice - but I am English only by geography and as far as I am aware there is no other way to do such work efficiently, and better still to do it well. It may be that I take it too seriously, but when I observe the general level at which slang is considered, by all but a few respected colleagues, I realise that so doing is almost a duty. Despite the caricatured version that the media feel safer in conveying, slang, with its subversive, oppositional heart, is a hugely important part of language: of any language which possesses such a register. It is language at its most human, and its study brings us into contact with our own humanity, even if, we cannot pretend otherwise, we are forced to focus on its worst characteristics. But then that is slang's point of departure, and why it counts. 'He moved,' as Thackeray put it in The Eustace Diamonds, 'from conventional language into rough, truthful speech' (Trollope 1872: Ch. L). So too does slang. And the slang lexicographer has no choice but to follow.

\section{Notes}

1. Though to what extent, given the paucity of cites, cant was 'commonly called the Slang Patter' even in 1758 remains debatable. The next such use is not until a ballad of the 1780s.

2. 'Bee' was the sporting journalist John Badcock; his dictionary of 'The Turf, the Ring, the Chase, the Pit, the Bon-Ton, etc.' had appeared in 1821.

3. Toldervy himself knew 'the slang' as well. Among the hundred plus examples in his play are dewbeaters, shoes, fribble, an impotent male, and corner-cupboard, the vagina.

4. Personal communication.

5. And that same year I had just published a book on the period.

6. It is that difference that is called up by the supporters of Ebonics - African-American Vernacular English - to trump those who dismiss that form of speech as 'just a bunch of slang'. There is much slang within Ebonics, but it is not the language's entirety, nor does the speech style lack ascertainable rules.

\section{References}

Adams, Michael (2003): Slayer Slang. New York: Oxford University Press. (2009): Slang: The People's Poetry. New York: Oxford University Press.

Bailey, Nathan (1730): Dictionarium Britannicum. London: T. Cox.

Balzac, Honoré de (1970): A Harlot High and Low. [Splendeurs et Misères des Courtisanes, 1847]. Trans. by R. Heppenstall. Harmondsworth: Penguin. 
Caldwell, J.P. (1870): “The Rationale of Slang”. Overland Monthly IV, 2 (California, February, 1870), 187-90.

Chereau, Ollivier (1628): Le Jargon ou Langage de l'Argot reformé [...]. Tiré et recueilli des plus fameux argotiers de ce temps. 2nd ed. Paris: La Veuve du Carroy.

Coleman, Julie (2012): The Life of Slang. Oxford: Oxford University Press.

Coles, Elisha (1676): An English Dictionary. London: S. Crouch.

Dumas, Bethany K. and Jonathan Lighter (1978): “Is Slang a Word for Linguists?". American Speech LIII, 1: 5-17.

Eble, Connie (1996): Slang and Sociability. Chapel Hill, NC: The University of North Carolina Press.

Eliot, George (1872): Middlemarch. Edinburgh and London: William Blackwood \& Sons.

Fernald, James Champlin (1918): Expressive English. New York: Funk \& Wagnalls.

Freud, Sigmund (1964): New Introductory Lectures on Psychoanalysis. [Neue Folge der Vorlesungen zur Einführung in die Psychoanalyse, 1933]. Vol. XXII of The Standard Edition of the Complete Psychological Works of Sigmund Freud. Trans. and ed. by J. Strachey. London: Hogarth Press and the Institute of Psychoanalysis.

Gale Cengage Learning. (n.d.) <http://www.gale.cengage.com/free_resources/glossary/glossarys.htm>. (Accessed 2011).

Genung, John Franklin (1893): Outlines of Rhetoric. Boston: Ginn.

Green, Jonathon (2008): Chambers Slang Dictionary. Edinburgh: Chambers. (2010): Green's Dictionary of Slang. London: Chambers.

Grose, Francis (1785): A Classical Dictionary of the Vulgar Tongue. London: S. Hooper.

Hotten, John Camden (1859): A Dictionary of Modern Slang, Cant, and Vulgar Words. London: John Camden Hotten.

- (1873): The Slang Dictionary. London: John Camden Hotten.

Hugo, Victor (1928) : The Last Day of a Condemned Man. [Le Dernier Jour d'un Condamné, 1829]. In The Works of Victor Hugo. One Volume Edition. Roslyn, NY: Black's Reader's Service.

Lighter, Jonathan E. (2001): "Slang". In John Algeo, ed., The Cambridge History of the English Language. Vol. VI: English in North America. Cambridge: Cambridge University Press, 219-252.

Matthews, Brander (1901): Parts of Speech. New York: Charles Scribner's Sons.

McMillan, James B. (1978): “American Lexicology 1942-1973”. American Speech LIII, 2: 141-163.

Millhauser, Milton (1952): “The Case Against Slang”. The English Journal 41, 6 : 306-309.

Moore, John (1961): You English Words. London: Collins.

Partridge, Eric (1933): Slang To-day and Yesterday. London: Routledge \& Sons.

- (1966): Origins: A Short Etymological Dictionary of Modern English. 4th ed., rev. and addns. London: Routledge \& Kegan Paul.

Pennac, Daniel (2010): School Blues. [Chagrin d'École, 2007]. London: MacLehose Press.

Skeat, Walter W. (1909): Etymological Dictionary of the English Language. New ed., rev. and enl. Oxford: Clarendon Press.

S.R. [Samuel Rowlands] (1610): Martin Mark-all, Beadle of Bridewell. London: Printed [by John Windet] for Iohn Budge, and Richard Bonian.

Trollope, Anthony (1872): The Eustace Diamonds. New York: Harper \& Brothers. 